Historic, Archive Document

Do not assume content reflects current scientific knowledge, policies, or practices. 


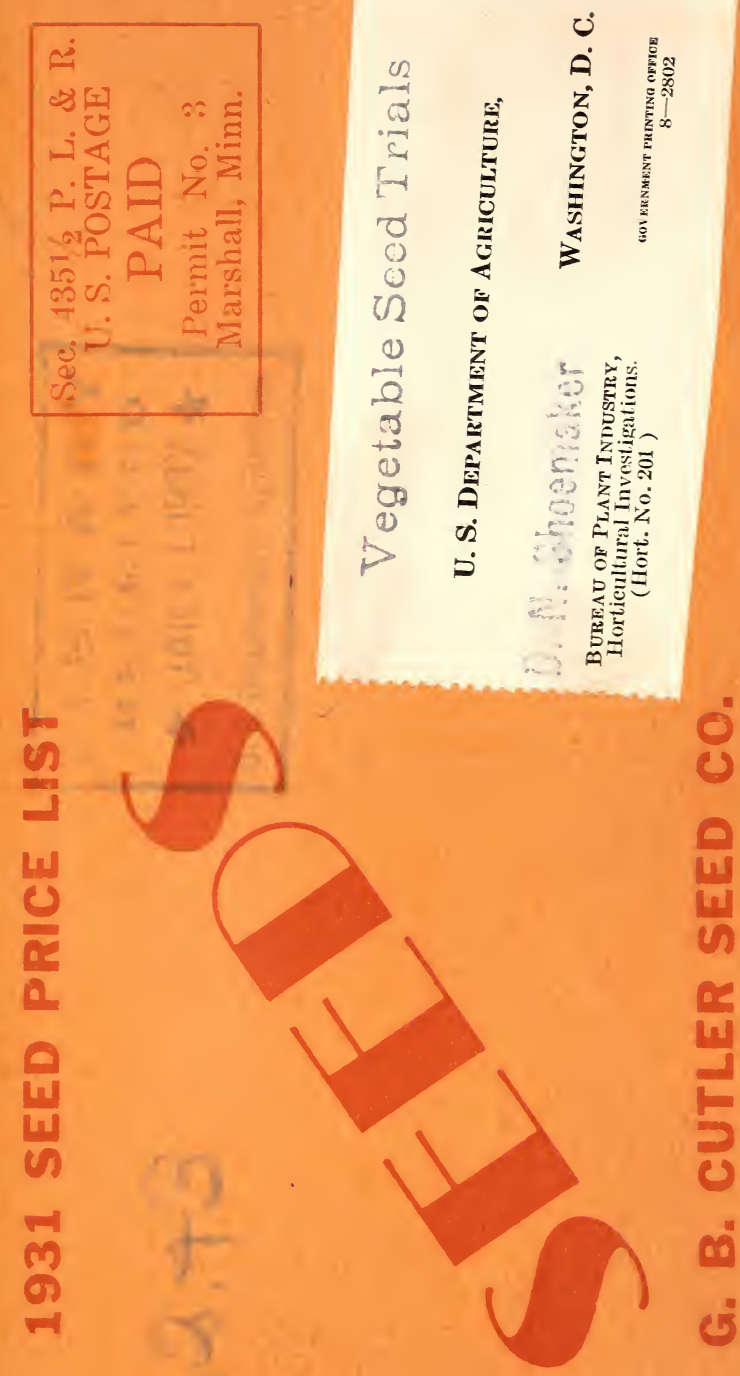

( 5 iv $\frac{9}{6}$ ㄴ. 6 115 025 is 5 둥 $\Rightarrow$ 둔 (2) 1 a 13 


\section{K-E-E-P T-H-I-S}

Write When in The Markit

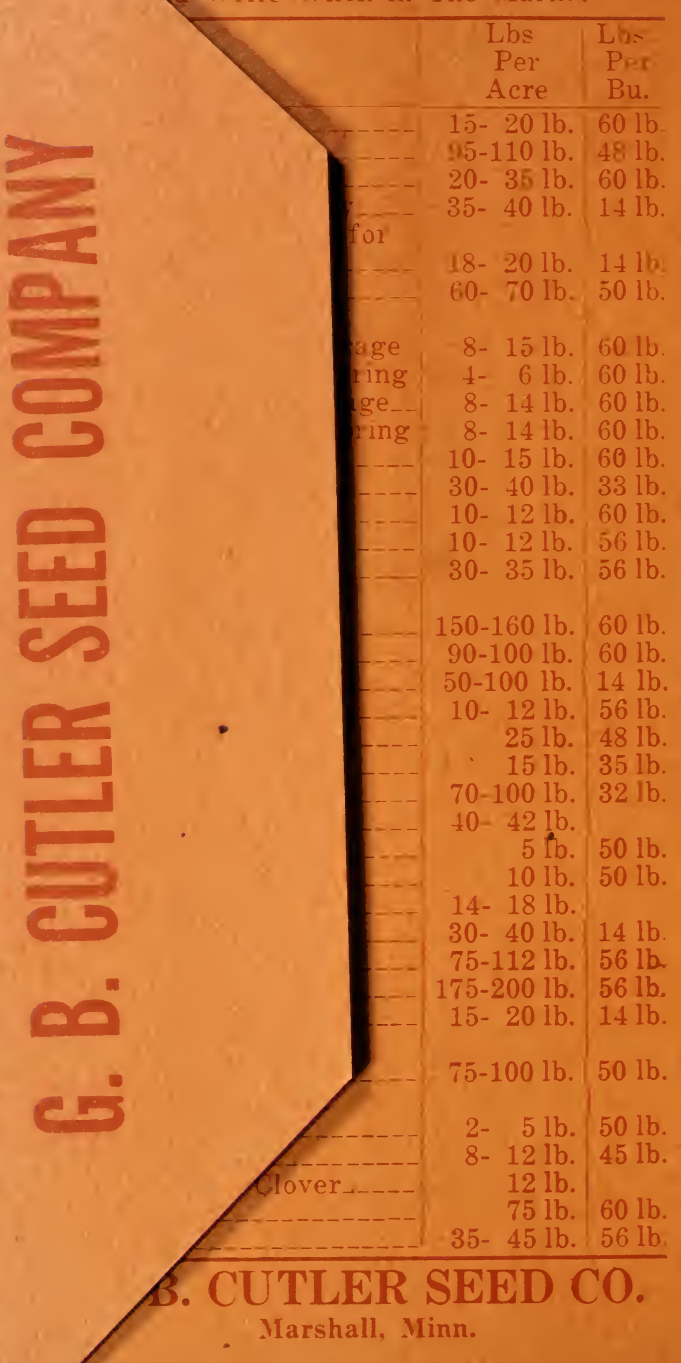




\section{The New Head.}

In looking over our 1928 catalog we started with a new head and it worked all right so this year it will still be the same

\section{G. B. CUTLER SEED CO.}

The management will be the same as always, as I guess it is not so bad, as our business is on the increase.

Now if you want to see the real head turn this page over and take a good look.

\section{GEO.}

Listen in on KSOO, Sioux Falls, between 4 and $4: 30$ each day. 


\section{K-E-E-P T-H-I-S}

And Write When in The Marlint

\begin{tabular}{|c|c|c|}
\hline & $\begin{array}{l}\text { Lbs } \\
\text { Per } \\
\text { Acre }\end{array}$ & $\begin{array}{l}\text { Las } \\
\text { Pan } \\
\text { Eo. }\end{array}$ \\
\hline Alfalfa drelled & $15-20 \mathrm{Ib}$ & 6016 \\
\hline Barley _- & $95-110 \mathrm{Jb}$ & $48 \mathrm{lh}$. \\
\hline Beans, in hills & $20-35 \mathrm{lb}$. & $60 \mathrm{ik}$ \\
\hline $\begin{array}{l}\text { Blue Grass, Kentucky } \\
\text { Brome Gras, alone for }\end{array}$ & $85-40 \mathrm{lb}$. & $14 \mathrm{lb}$ \\
\hline hay & $18-20 \mathrm{lb}$. & 1410 \\
\hline Buckwheat ..... & $60-70 \mathrm{lb}$ & 50 ไh. \\
\hline Clover & & \\
\hline $\begin{array}{l}\text { Alsile, alone for forage } \\
\text { On wheat, rye in spring }\end{array}$ & $\begin{aligned} 8-15 \mathrm{lb} . \\
4-6 \mathrm{lb} .\end{aligned}$ & $\begin{array}{l}60 \mathrm{Jb} \\
60 \mathrm{lb}\end{array}$ \\
\hline Red, alone for foliage & $8-14 \mathrm{lb}$. & $60 \mathrm{lb}$ \\
\hline In small grain in spring & 8- $14 \mathrm{lb}$. & $60 \mathrm{lb}$. \\
\hline Sweet, hulled --- & $10-15 \mathrm{lb}$. & $60 \mathrm{lb}$. \\
\hline $\begin{array}{l}\text { Sweet, unhulled } \\
\text { White }\end{array}$ & $30-40 \mathrm{lb}$. & $33 \mathrm{lb}$. \\
\hline Coin & $\begin{array}{l}10-12 \mathrm{lb} . \\
10-12 \mathrm{lb} .\end{array}$ & $56 \mathrm{Ib}$. \\
\hline Corn, for silage & $30-35 \mathrm{lb}$. & $56 \mathrm{lb}$. \\
\hline Canada Field Peas & & \\
\hline Broadeast _... & $150-160 \mathrm{lb}$. & $60 \mathrm{Ib}$ \\
\hline With Oats _._ & $90-100 \mathrm{lb}$ & $60 \mathrm{lb}$ \\
\hline Grass, for lawns -- & $50-100 \mathrm{lb}$. & $14 \mathrm{lb}$ \\
\hline $\begin{array}{l}\text { Faffir, for fodder } \\
\text { Millet }\end{array}$ & $\begin{aligned} & 10- 12 \mathrm{lb} . \\
& 25 \mathrm{lb} .\end{aligned}$ & $\begin{array}{l}56 \mathrm{lb} \\
48 \mathrm{lb}\end{array}$ \\
\hline Millet, Japanese - & $\rightarrow \quad 15 \mathrm{lb}$ & $35 \mathrm{lb}$ \\
\hline Oats & $70-1001 \mathrm{~b}$. & $32 \mathrm{lb}$ \\
\hline $\begin{array}{l}\text { Pasture Mixture } \\
\text { Rape, with grain }\end{array}$ & 40- $\begin{array}{r}42 \mathrm{lb} . \\
5 \mathrm{lb} .\end{array}$ & $50 \mathrm{lb}$ \\
\hline $\begin{array}{l}\text { Rape, broadcast --- } \\
\text { Red Top, solid seed }\end{array}$ & 14- $10 \mathrm{lb}$. & $50 \mathrm{lb}$ \\
\hline Red Top, in chaff & $30-40 \mathrm{lb}$. & $14 \mathrm{lb}$ \\
\hline Rye & $75-112 \mathrm{lb}$. & $56 \mathrm{lb}$. \\
\hline Rye, forage & $175-200 \mathrm{lb}$. & $56 \mathrm{lb}$. \\
\hline $\begin{array}{l}\text { Rye, grass } \\
\text { Sorgum, forage, }\end{array}$ & & \\
\hline & $75-100 \mathrm{lb}$ & $50 \mathrm{lb}$ \\
\hline $\begin{array}{l}\text { Sorgum, for seed or } \\
\text { syrup }\end{array}$ & $2-$ & 501 \\
\hline Timothy _. & 8- $12 \mathrm{lb}$. & $45 \mathrm{lb}$. \\
\hline Timothy and Clover..-- & $12 \mathrm{lb}$ & \\
\hline $\begin{array}{l}\text { Wheat } \\
\text { Flax }\end{array}$ & $35-45 \mathrm{lb}$. & $501 \mathrm{~b}$ \\
\hline
\end{tabular}




\section{The New Head.}

In looking over our 1928 catalogwe started with a new head and it worked all right so this year it will still be the same

\section{G. B. CUTLER SEED CO.}

The management will be the same as always, as I guess it is not so bad, as our business is on the increase.

Now if you want to see the real head turn this page over and take a good look.

\section{GEO.}

Listen in on KSOO, Sioux Falls, between 4 and $4: 30$ each day. 
G. B. CUTLER SEED CO.

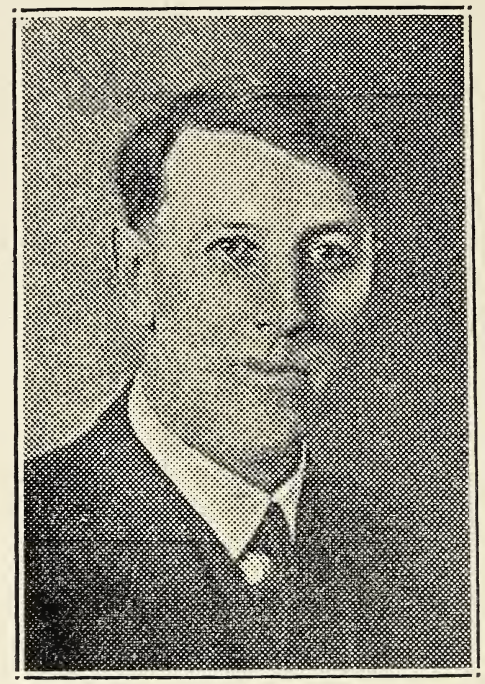

GEORGE

When in Marshall come and see me any time. Can be found at 75-77 W. Second Street on the Bank of the Roaring Redwood River. 


\section{Thirteenth Annual}

\section{PRICE LIST \\ -OF THE-}

G. B. CUTLER SEED CO.

Marshall, Minn.

\section{March 1st, 1931}

In presenting you this 1931 Price List, we wish to thank all our friends and customers for their past patronage.

Our old customers are well acquainted with our ways of doing business, and you should ask the old if in doubt as to our square dealings.

No Warranty.-We exercise extreme care in the filling of all orders, but we give no warranty, expressed or implied, as to the quality, description or productiveness, or any other matter of any seeds we send out, and will in no way be responsible for the crop. 
This non-warranty is similar to that used by all seed houses and we recommend that you test all seeds on arrival and if they do not meet your requirements, return them at once at our expense and we will cheerfully refund your money.

ORDEI EARLY-As market conditions are not yet normal, and as fancy stocks are going to be hard to replace, we strongly recommend that our customers place their orders early, thereby taking advantage of the low prices which we present in this first issue of our 1931 Price List.

Prices Subject to Change.-The prices quoted herein are based on market conditions at the time this list is isisued and are subject to change without notice. We do not alter prices except in extreme cases, but if your list is an old one and you have occasions to presume that prices are either higher or lower, just write us for current list before ordering and we will supply one at once.

Orders Promptly Filled.-In case of delay you will be riotified by letter explaining the cause of such delay and advised when shipment will be made. If you do not hear from an order sent us within a reasonable 
length of time, send us a duplicate, stating amount of remittance, and be sure to give your name and full address.

Terms of Sale-Cash must accompany orders and should be in the form of Money Order or Bank Draft, Currency or Registered Mail, or Bank Check.

G. B. CUTLER SEED CO.

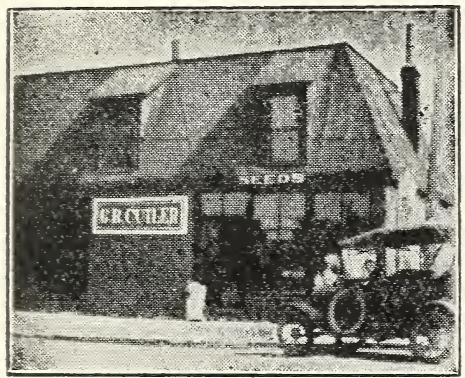

THE PRESENT HOME OF THE MARSHALL SEED HOUSE.

BEMIS “A” GRAIN BAGS, Each 35c 


\section{Just a Few Words From George}

(A copy from last year's catalogue)

It seems to be customery for a Seed Man to tell a little of his history. Of course it likely will be better not to tell everything that has happened in his life as we were all boys at one time and did things, such as swiping grapes, watermelons and several other things that might not look good in print. A few years ago while visiting my old home town, Marshall, Wisconsin, I heard several things that I did when a boy that I had forgotten until reminded of it. I will admit that I never was an angel, but did always manage to keep out of jail. Now when a boy of 12 or 14 years old I always had several seed catalogs and thought I wanted to be a seed man and I went as far as to write several asking for a job, but they all wrote me a very nice letter saying that they all had plenty of help and from then on the seed game was a thing of the past.

Twenty-nine years ago I came to Marshall, Minn., the best town and state that I know of. I worked out on a farm the first year here for $\$ 20.00$ per month and then rented my folks' farm $21 / 2$ miles east of 
Marshall and was there 15 years. Eight of them was spent in batching, when I found a girl at Chatfield, Minnesota that felt sorry for me and have had a good cook and three meals a day since. I cannot tell you what she thinks of me now, but to be honest with you I have heard her say that I was the best man she ever had, (as I am the only one she has had.)

Thirteen years ago I became good, come to town and bought a church parsonage to live in and I rented the old Catholic church and started in the seed business. Seed corn being about all that I had the first year, if I remember right, I had six sacks of grass seed and carried about one half of that over until the next year, but business has grown until in my present location, that instead of getting in seed by the sack as at first, it is shipped in, in car load lots now. Until nine years ago I did not handle garden seeds at all, but since have handled them in bulk. This department has grown just as fast if not faster than the field seed, as in the bulk garden seed buyer I never lose a customer. After they buy that way once they never go back to the pretty packages with very few seeds in them and perhaps they are 10 years old as far as the dealer you buy 
them of knows. As to the chicken feed, that has grown from nothing a few years ago, until now that is shipped in by the car load.

Now to sum this all up there must be a reason for this growth in the past years. I do not know what it is unless it is by trying hard to please the people and selling them what they. want at the right price. Of course we make mistakes but if we do we are always glad to correct them, (some times at a loss), which we are glad to do if it is our fault. You are just as welcome in this place with overalls on as you are with a white collar and it will always be so as long as I run things around here.

Come in and see us whether you buy anything or not as we always like company. Perhaps I have said more than I ought to but it is too late now. When you come in say Hello George, leave the Mr. stuff off and oblige.

Thank you

G. B. CUTLER

\section{Vacation}

In most of my small seed catalogues, I have stated to you a brief story of what the Seed Man did 
during the summer after his busy season closed, about July 1st.

This year our vacation was somewhat tame. My family have become tired of traveling and camp life here, there and everywhere for the past ten years, therefore we tried something different this year.

We rented a cottage at Lake Shetek thirty-five miles south of Marshall for three weeks in the hottest part of the summer. We have decided that this is probably what we shall do this coming season as they all seemed to have a very enjoyable time.

We were near enough to the best little city in southwestern Minnesota to make frequent trips home, to get our mail, see lots of people we knew and some we didn't know but would like to know.

We were twelve miles from Tracs a very nice little city but of cours not quite as good as our own as there are not many like Marshall.

The people were in general very nice and friendly and to our pleasure on leaving we found we ha made many very good friends from Tracy and surrounding territory and will be glad to have you all come in to see us at any time.

Enough said.

GEORGE. 


\section{Sweet Clover SCARIFIER}

Having just installed a new modern Scarifier we are able to do you a better job and in less time than before. Bring in your Sweet Clover-have it scarified and cleaned. Our price is $\$ 1.00$ per cwt.

\section{Medium Red Clover}

This seed is grown in Minnesota, cleaned in fine shape and is the best grade to be had.

Price per 1b........27c

\section{Sweet Clover}

All of this seed is scarified White Blussom (Home grown), 1st grade _._._._._._._. $9 \mathrm{c}$ $2 \mathrm{~d}$ grade $\ldots \ldots \ldots$ Yellow Blossom, per pound_---_10

\section{Grundy Co. or Dwarf Sweet Clover}

This is something new in this territory. It is a great deal finer, more like alfalfa. Makes better hay than common sweet clover.

Per lb............9c 


\section{Alsike}

This is by all means the best clover for a low land pasture.

Price per lb........27c

\section{White Dutch Clover}

This is the kind to sow on your lawn. Also good in a pasture mixture.

Per lb..........50c

\section{Alfalfa}

Our seed all comes to us in sealed and branded bags, and is of the 1st grade. You have likely been hearing over the radio about the cheap seed you can buy. If you have, send for sample and see then if you want the grade of seed advertised.

\section{Northern Grown Alfalfa}

This does not need any explanation as everybody knows how good it is and every farm should have a few acres.

Do not buy Alfalfa seed that is offered cheap as it may be southern grown seed which is always cheaper than northern grown seed. The southern grown alfalfa, grown from 
this seed will not stand our cold winters.

Cossack _...

Grimms

Dakota No.

\section{Nitragin}

Inoculate your alfalfa and clover with Nitragin for best results.

$1 / 2$ bushel size can_._._._._._. $60 \mathrm{c}$ 1 bushel size can

\section{Grass Seeds}

Timothy, price per pound_____11c Timothy and Alsike Clover mixed

20 per cent Alsike, 80 per cent

timothy, price per pound_-_-15c Red Top, price per pound___._-30c Blue Grass, price per pound_-_- 50 c Bromus, price per pound____.__ 25c

\section{Dwarf Essex Rape}

This seed is grown in Holland and sure is the quickest pasture for cattle, hogs and sheep when sown in spring. For fall pasture nothing gives more cheap feed than Rape sown in small grain. Price per cwt._-_- $\$ 9.00$

\section{Sudan Grass}

A great one year hay and pasture grass; can be cut for hay two or three times a season, a little coarse, but very good feed. Price per cwt.- $\$ 11.0$ 


\section{Amber Cane}

One of the greatest fodders-if mixed with corn. Price per cwt. $\$ 6.00$

\section{Kaffir Corn}

If cut green makes fine fodder. If allowed to ripen, is one of the best feeds for chickens. per cwt._._-\$6.00

\section{Sun Flower}

In a real dairy country this is getting to be quite a popular crop to put in a silo for the dairy cow. When raised for the seed is a good feed for poultry. Price per pound_._._._-_20c

\section{Field Peas}

A crop of field peas and oats, cut for hay, has proven itself nearly as good as alfalfa, sown at the rate of one bushel peas, one bushel oats is a good mixture. Price per cwt._-- $\$ 8.00$

\section{Sweet Clover Scarifier}

If you have any sweet clover that you want cleaned and scarified we will be glad to do it for you at a reasonable price of $\$ 1.00$ per cwt.

We also clean any other seed that you might have that you want cleaned.

BEMIS “A” GRAIN BAGS, Each $35 e$ 


\section{Millet}

Siberian, per cwt. _._._-_._ $\$ 4.00$ German, per cwt.___________\$ $\$ 4.00$

\section{Soy Beans}

Manchu, per cwt._-_____-_-_\$5.50

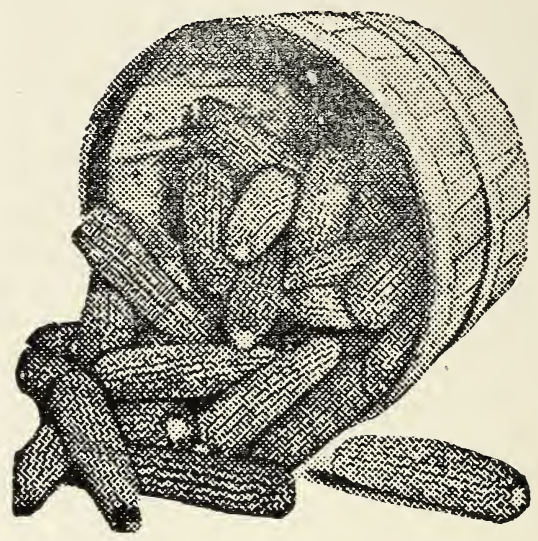

\section{Seed Corn}

At the present time we are not able to tell you just what we will have as we do not know just how it will germinate later and cannot quote you a price, but when you are in the market later, let us hear from you. 


\section{Clipper Cleaner}

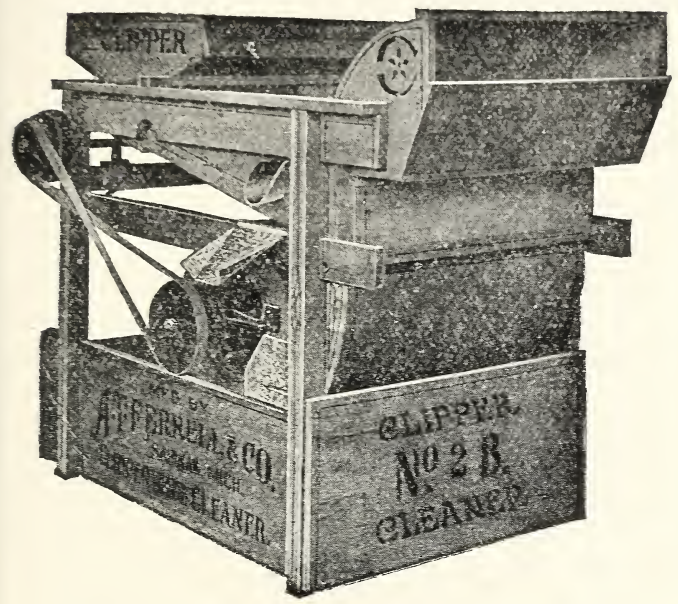

This year we are selling the Clipper Mills and as you all know this is the best mill for cleaning all kinds of grain and seed. Screens for all purposes.

They come complete with 12 screens and for motor or hand power.

No. 1 Clipper...... $\$ 39.00$
No. 2 Clipper. . . . \$46.00 


\section{Garden Seeds}

Why pay two prices for your garden seed done up in packages with a pretty picture on it? If you do soyou have to pay for the picture extra.

Our seeds are in plain packages with as many or more seeds for less money. If you would like different varieties not listed below we can furnish same.

We pay postage on all garden seed. If you want package seeds will furnish them at 5 cents per package.

\section{Beans}

Golden Wax, per pound___._._-_35c Black Wax, per pound_._..._._-_35c Stringless Green Pod _._._._._-_ $35 \mathrm{c}$ Bush Lima, per pound___-___._- 35 c Navy, per pound Red Kidney --

\section{Peas}

Little Gem, per pound _._._._._. $35 \mathrm{c}$ Everbearing, per pound_._-_-_-_35c Telephone, per pound Dwarf Sugar (Edible Pod) 1b._-_-_35c

\section{Sweet Corn}

Evergreen _._._._._._._. $20 \mathrm{c}$ Golden Bantam__.________ 20c

Popcorn

Japanese Hulless $15 \mathrm{c}$ 


\section{Beets}

Blood Turnip

Swiss Chard__._._._._. $.10 \quad 1.00$

Long Red Mangle___-__- .08 $\quad .50$

Sugar _._-_._. $10 \quad 1.00$

\section{Onions}

Red Globe

White Portugal__-_-_-_- .15 2.00

Yellow Danvers__-_-__-_.15 2.00

\section{Cucumbers}

Early White Spine_-_-_- .10 1.00

Long Green__._._._. $10 \quad 1.00$

Boston Pickling

\section{Lettuce}

Black Seeded Simpson_-- .15 1.50

Early Curled Simpson_-_- $.15 \quad 1.50$

Prizehead _._._-_._._. .15 1.50

Grand Rapids _._._._-_. $15 \quad 1.50$

California Cream Butter

Head _._._._._. $15 \quad 1.50$

\section{Radish}

Long Scarlet__-_-_-_-_ $.10 \quad 1.00$

French Breakfast_____- .10 1.00

Early Scarlet Turnip_-_- .10 1.00

Early Scarlet Turnip

White Tip _._- .10 1.00

Long White Icicle_____-_.10 1.00

China Rose (winter) _..-- $.10 \quad 1.00$ 


\section{Spinach}

Long Standing

New Zeiland____-_-___-_. $10 \quad 1.00$

\section{Cabbage}

Early Flat Dutch______- .15 1.50

Late Flat Dutch

Early Jersey Wakefield_- .15 1.50

Late Drumhead__-_-_-_. $.15 \quad 1.50$

Savoy _-_-_-_-_-_-_-_. $15 \quad 1.50$

Red Rock _._._-_._- $15 \quad 1.50$

Chinese _...... 15

\section{Tomatoes}

Earliana _._._._._._. $.15 \quad 2.00$

New Stone

Favorite _._._._._._._. $.15 \quad 2.00$

\section{Squash}

Hubbard _-_-_-_-_- $.10 \quad 1.00$

Table Queen__._-_-_-_. $.10 \quad 1.00$

Summer _._-_-_-_-_-_- .10 1.00

\section{Watermelon}

Tom Watson

Coles Early _._._._-_. $.10 \quad 1.00$

Harris Early__-_-_-_-_. $10 \quad 1.00$

Kleckney Sweet__._-_-_. $.10 \quad 1.00$

Winter Queen__._._-_. $10 \quad 1.00$

\section{Muskmelon}

Banana _._. $10 \quad 1.00$ 
Rocky Ford

$$
.10
$$

Early Hackensack _-__-_ .10 1.00

Honey Dew________. $.10 \quad 1.00$

Osage _._............. 10

\section{Dill}

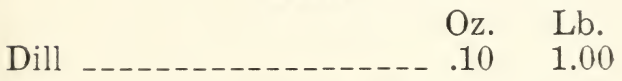

\section{Pumpkin}

Field _._._-_._. .050 Sugar or Pie _._._._._- . $10 \quad 1.00$

\section{Kohi Rabi}

Early White___-__-_-_. 152.00

\section{Carrot}

One-half Long_-_-_-_-_.10 1.00 Oxhart _._-_._-_... .10 1.00

\section{Turnip}

Purple Top_____-_-_-_.10 1.00

\section{Rutabaga}

American Purple Top_-_- .10 1.00

\section{Celery}

White Plume_____-_... $15 \quad 2.00$

\section{Salsify}

Vegetable Oyster__-_-_-_.20 3.00

\section{Parsnip}

Hollow Crown__.___. $10 \quad 1.00$

\section{Parsley}

Champion Moss Curled_-- .10 1.00 


\section{Onion Sets \\ Bermuda Onion Plants}

Will have a good supply in season and will be able to sell them as cheap or cheaper than you can get them elsewhere.

\section{Frost Proof Cabbage Plants} Early or Late

In season

50 Plants, postpaid__-_-_-_-_-_30c 100 Plants, postpaid $.55 \mathrm{c}$

\section{Tomato Plants}

Large strong and healthy plants

1 Doz. Plants, postpaid___-___-_15c

5 Doz. Plants, postpaid_-_-_-_-_65c These plants are all cheaper if you call for them here.

\section{Flower Seeds}

Oz. Lb.

Sweet Peas, mixed___-_- $10 \quad 1.50$ Nasturtiums, mixed dwarf .10 1.50

Any other flower seeds that you may want will furnish at FIVE and TEN CENTS a package.

When you need seeds, remember that G. B. Cutler Seed Co. offers only the best in seeds. A trial order will convince you. 


\section{Chick Feed}

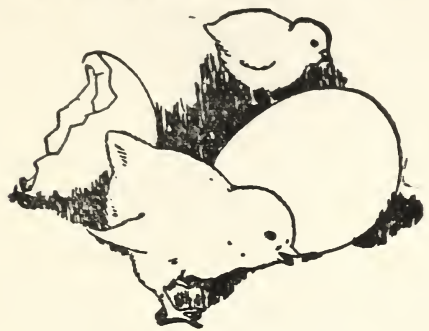

All chicken raisers know that a good balanced ration is always best for the growing chick, and also that a good mixed feed is better than one kind of feed all the time.

$25 \mathrm{lb} .100 \mathrm{lb}$. Sack Sack

Peerless Chick Feed

(with corn) _._._._.80 $\$ 2.60$ Peerless Chick Starter

(oncoln) _..._._._. $.85 \$ 2.75$ Chick Mash (with but-

termilk) _.-_-_-_-_. $.90 \quad \$ 3.25$

\section{SHEPS PLANT SPRAY \\ (NON-POISONOUS)}

Get rid of destructive insects. Use SHEPS Plant Spray. Kills and controls both sucking and chewing insects but absolutely harmless to humans, birds, animals and pets. Will not "burn" delicate leaves or fiowers. Makes green, healthy, lustrous foliage. No soapsud solution needed-simply mix with water.

\section{PRICES POSTPAID}

2-0z. Bottle (makes 4 gals. Spray Solution)... \$ .35

8-0z. Bottle (" 16 " " ").... .75

Pint Bottle ( " 32 " " " " $\quad$ ".....

Quart Can (" 64 " " ").... 2.00

Bulk Prices on Request. 


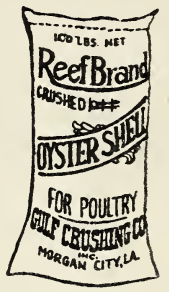

FOR ALL KINDS OF POULTRY 100-Lb. Bag, Hen Size

\section{CHARCOAL}

50-Lb. Bag Charcoal___-_-_-_-_-_-_ $\$ 2.25$

Small Lots, Per Pound__-_-_-__________5e

MEAT SCRAPS AND BONE MEAL

100-Lb. Bag Meat Scraps_________ $\$ 3.50$

25-Lb. Bag Meat Scraps__________ $\$ 1.10$

100-Lb. Bag Bone Meal__-_-_-_-_-_\$3.00

25-Lb. Bag Bone Meal _-_-_._- .90

\section{Shellmaker}

A SUBSTITUTE FOR OYSTER SHELLS 25-Lb. bag -_-_-_-_-_-_-_-_ $40 \mathrm{c}$ 100-Lb. bag

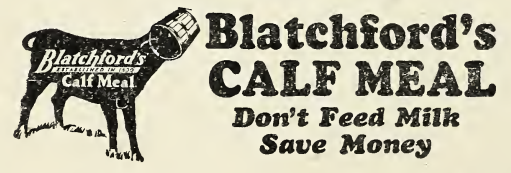

25 lb. bag. . . . . . . \$1.70 


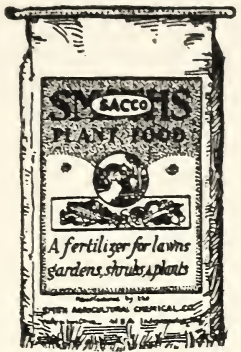

\section{MAKES THINGS GROW}

SACCO is a specially prepared PLANT FOOD for the development of fine LAWNS, GARDENS, SHRUBS, FLOWERS and TREES. It has the endorsement of highest authorities on plant nutrition.

SACCO is very effective and economical. A light application once or twice a year, of 2 to 4 pounds per hundred square feet, will keep the lawn in excellent growing condition.

SACCO has more than four times as much plant food value as pulverized manures. Full directions for use on each package.

CLEAN-ORDORLESS-Easy to Apply

1-Lb. Can _-_-_-_-_-_-_-_-_-_-_-_ $\$$.

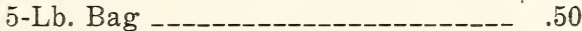

10-Lb. Bag --_-_-_-_-_-_-_-_-_. $\quad .85$

25-Lb. Bag --_-_-_-_-_-_-_-_-_-_- 1.75

50 -Lb. Bag -_- 3.00

$100-\mathrm{Lb}$. Bag -__-_ 5.00

THE PLANT FOOD Without an EQUAL!

\section{Dandelion Destroyer}

Clean your lawn of dandelions, USE WEDO and you will not be bothered any more.

25 lbs. . . . . . . . . \$1.75 


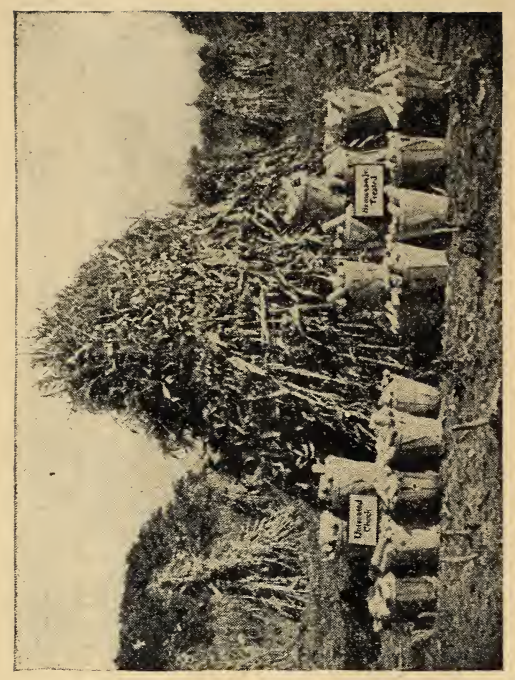

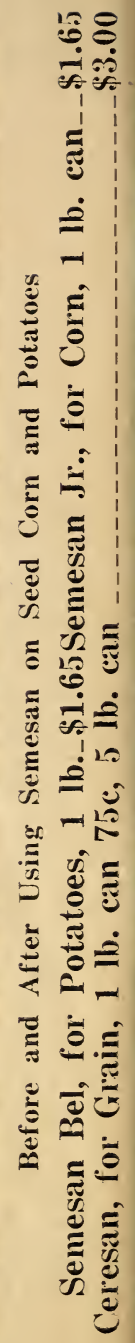

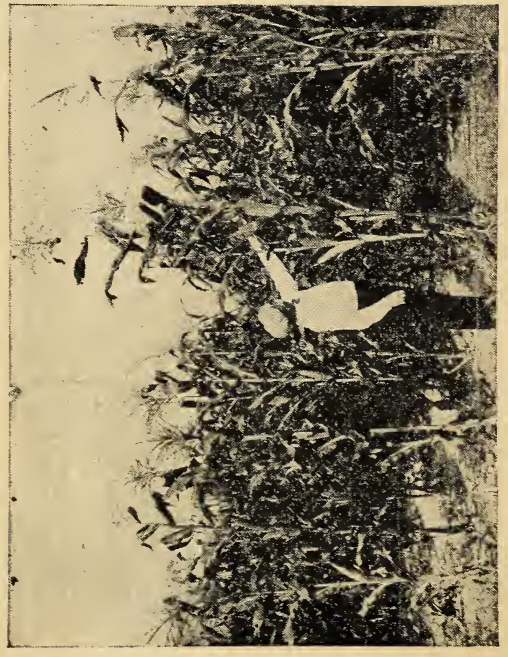




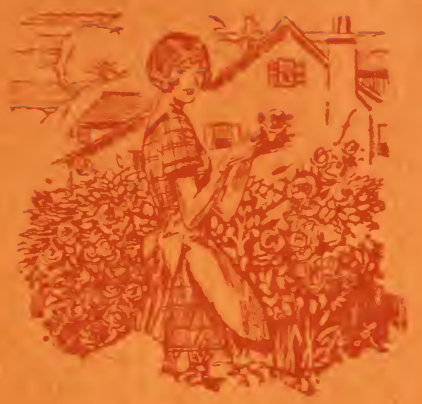

For

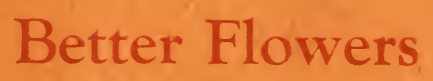

- and more of them

use good seed, buibs and plants, and feed them Vigoro, the complete, balanced diet. Feed your lawn, regetables, shrubs, and trees, too.

Clean, odorless, easy to use, and economical.

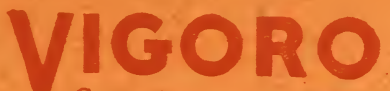

Complete plant food

100 lb. bag _..._. $\$ 5.00$

50 lb. bag _._._. 3.00

$25 \mathrm{lb}$. bag _...... 1.75

5 lb. bag $\ldots .50$

12 oz. pkg........ .10

For Lawns, Gardens, Flowers, and Trees 
